Bősze Péter orvos professzor, Fóris Ágota nyelvész professzor, Kiss Jenő nyelvész, professor emeritus, az MTA rendes tagja, Gózon Ákos tudományos újságíró, Kurtán Zsuzsa nyelvész professzor, Péntek János nyelvész professzor, az MTA külső tagja, Szabó T. E. Attila biológus professzor. A kuratórium elnöke: Péntek János.

2018-ban Tamás Dóra egyetemi adjunktus, terminológia-kutató volt a díj kitüntetettje, Bárth M. János egyetemi adjunktus, Szabó T. Attila történeti helynévanyagának gondozója különdíjat kapott. 2019-ben Kuna Ágnes egyetemi adjunktus, terminológia-kutató kapta a díjat, N. Fodor János egyetemi adjunktus, történeti személynévkutató a különdíjat.

Ebben az évben a kuratórium úgy döntött, hogy a díjat Bartos-Elekes Zsombornak, a kolozsvári egyetem Magyar Földrajztudományi Intézete docensének ítéli oda a többnyelvü területek névhasználata, az erdélyi magyar térképi és hivatalos névhasználat, a mesterséges névadás és névstandardizáció területén kifejtett nemzetközileg is jelentős munkásságának elismeréseként.

PÉNTEK JÁNOS

Babeş-Bolyai Tudományegyetem

\title{
Búcsú Éder Zoltántól
}

(1931-2020)

Ismét szegényebbek lettünk: 2020 január 3-án itt hagyott bennünket Éder Zoltán Babits-kutató, italianista, hungarológus, a Nápolyi Egyetem vendégtanára, nyelvtudomány-történész, az ELTE BTK nyugalmazott habilitált lektorátusvezető docense, elismert bibliográfus, a régi könyvek szerelmese.

Életrajzának száraz tényei: 1931-ben született, szimbolikus napon, április 11-én, Márai Sándor és József Attila születésnapján, és amely napot 1964 óta a költészet napjaként ünnepelünk. Családja (jogász édesapja, német-francia szakos tanárnő édesanyja), iskolái biztos szellemi alapot nyújtottak későbbi tanári, tudósi pályájához. Az elemi iskoláit lakóhelyén, Kispesten végezte, a gimnáziumot a bencéseknél Pesten, Kőszegen és Csepelen. Az egyházi iskolák államosítása miatt végül a kőbányai I. László gimnáziumban érettségizett. Olasz-magyar szakos tanári oklevelét az ELTE Bölcsészettudományi Karán szerezte 1955-ben. Több mint egy évtizedig oktatott gimnáziumokban. A diploma megszerzése után rövid kitérővel egy évet a csepeli Jedlik Ányosban, ahonnan 1956-os magatartása miatt - november 2-án a forradalmi vívmányok megőrzésére buzdította a diákságot - mennie kellett. Szorongatott helyzetében Gyalmos János, a Fővárosi Tanács Oktatási Osztályának vezetője volt a segítségére, aki áthelyezte a híres-nevezetes újpesti „Könyves”-be, amelynek 1957-től 1963-ig volt legendás olasztanára. Utána még három év következett a Szilágyi Erzsébet Gimnáziumban, majd követve az egyetemi évek alatt bontakozó érdeklődését a nyelvészet iránt, 1966-tól az MTA Nyelvtudományi Intézetének tudományos munkatársa lett, ahol egészen 1974-ig dolgozott. Ekkor ismét új fejezet kezdődött szakmai pályafutásában, ugyanis elnyerte a Nápolyi Keleti Egyetem vendégtanári pályázatát. A mediterrán dél-olaszországi városban öt éven keresztül oktatott magyar nyelvet, irodalmat, kultúrát, így behatóbb tapasztalatokat szerezhetett a magyar mint ide- 
gen nyelv tanításának, a magyar kultúra terjesztésének a területén. 1980-ban kinevezték az ELTE Központi Magyar Nyelvi Lektorátusának lektorátusvezető docensévé. Nyugdíjaztatásától, 1997-től 2001-ig a Pázmány Péter Katolikus Egyetem Bölcsészettudományi Karán adott elő egy számára ugyancsak kedves témából, a magyar nyelvtudomány történetéből.

Gazdag életmüvének főbb, könyvekben megtestesülő állomásai: Babits a katedrán (1966); Révai Miklós (1972), Benkő József nyelvészeti munkássága és az Erdélyi Magyar Nyelvmüvelö Társaság (1978); Assisi Szent Ferenc Virágoskertje (1978); Sándor István: Egy külföldön utazó magyarnak jó barátjához küldetett levelei (1990); Babits Mihály: A gólyakalifa (1997); Túl a Duna-tájon. Fejezetek a magyar müvelődéstörténet európai kapcsolatai köréből (2000); Játékfilológia (2001); Régi napok illata. Babits-tanulmányok (2002).

A munkák címei sokszálú szellemi kötődésről vallanak, Éder Zoltán ugyanis mind az irodalomtudomány, mind a nyelvészet, mind a müvelődéstörténet elhivatott müvelője volt. Babits nevének többszöri felbukkanása kötetcímeiben nem véletlen: az a tény, hogy a költő egykoron a Könyves Kálmán tanára volt, erős késztetést jelentett a fiatal, kutatói hajlandósággal bíró Éder Zoltán számára költészetének tanulmányozására, kiváltképpen kevésbé ismert tanáréveinek, meghurcoltatása történetének feldolgozására. Tíz esztendeig tartó alapos vizsgálódásinak eredménye, a Babits a katedrán címü könyve (1966) a Babits-szakirodalom máig megkerülhetetlen forrása, amely számos ponton árnyalja, teljesebbé teszi a magyar irodalomtörténet Babits-képét. Az e kötetből való Babits tanár úr Újpesten (1911-12) címü értekezés nemcsak a költő Újpestre kerülésének, az ott töltött rövid időnek a hủ krónikája, de a 10-es évek pontos ecsetvonásokkal megrajzolt pannója is.

Hogy az irodalomtudósi ambíciók ellenére mégis a nyelvészet mellett kötelezte el magát, az valószínűleg a Nyelvtudományi Intézetben töltött évtizednyi időnek köszönhető. Itt kezdetben a Lörincze Lajos vezetésével készült Nyelvmüvelő kézikönyv első kötetének munkatársa volt. Feltehetőleg ez a feladat ihlette több, a nyelvmüvelés témában született dolgozatát, de a Nyelvtudományi Intézetben talált rá igazi kutatási területére, a nyelvtudomány-történetre, amelynek számos hiányos lapját egészítette ki, üres lapját töltötte meg remekbe szabott, példás filológiai pontossággal megszerkesztett írásaival. Foglalkozott többek között Révai Miklóssal, Benkő Józseffel. (A róla szóló könyvével szerzett kandidátusi címet 1979-ben.) A 80-as években ugyancsak jelentős dolgozatokat publikált Sajnovics Demonstratiojáról, Gyarmathi Sámuel Nyelvmesteréről, a Pesti Egyetem magyart tanító székének első tanáráról, Vályi Andrásról, a kevésesetüséget a sokesetüséggel felváltó Verseghy Ferenc életmúvét pedig, amely több cikkének is tárgya, senki nem ismerte nála behatóbban. A Gyarmathi Sámuel Nyelvmesterének egyik fö forrása címü tanulmánya habilitációs értekezésének témája is lett (Magyar Nyelv 1995: 52-63, 140-56, 291-310). A közelmúlt jeles alakjai közül Szabó T. Attila életművének bemutatását köszönhetjük neki. Vele szoros, baráti kapcsolatban is állt.

Az említett munkák nemcsak Éder Zoltán kutatói, de emberi erényeinek, a hitről, az igazságról vallott nézeteinek is bizonyítékai: a felsorolt nevek viselöi ugyanis majdnem mind valamilyen szempontból méltánytalanul mellőzött, elfeledett, meghurcolt, de kiemelkedő értéket létrehozó képviselői voltak tudománytörténetünknek. Hosszasan dicsérhetném - egyetértve méltatóival - munkáinak erényeit, a filológiai pontosságot, gondosságot, a világos szerkesztést, az elegáns, könnyed előadásmódot. Ehelyütt azonban inkább a következetes kutatói magatartás mögött rejtőzködő kiapadhatatlan (gyermeki?) kíváncsiságról szólnék, amely szinte fáradhatatlanná tette, hajtotta, hogy mindennek utána járjon. 
Kitüzött céljainak teljesítése közben önfeledten szövögette tudományos történeteit: mindig az alapokból kiindulva pótolta a hiányzó láncszemeket, találta meg a térben és időben látszólag távoli dolgok, tárgyak, személyek közötti addig nem is sejtett összefüggéseket. S ha összeállt a kép, elnéző mosollyal figyelmeztetett: az igazság ez, a sötétség itt foglalta el a világosság helyét, látásunk ettől a kicsi folttól nem volt tiszta. Azt hiszem, játszott, kitartóan és felszabadultan. Ezt ő maga is érezte, hiszen nem véletlenül adta (Babits Mihály Játékfilozófia címü, 1912-ben keletkezett esszéjének hatására) a Játékfilológia címet egyik könyvének. Ebből a Stilisztika fejezet finom, légies etüdjeit emelném ki, amelyek ékes bizonyítékai szerzőjük érzékenységének, az irodalom, a nyelvészet határain átlépő egyetemes müveltségének. Születésük ihletője lehetett egy mindennapi szókapcsolat (,te meg én”), egy csodálatos idézet valamelyik kedves költőjétől, leginkább Aranytól, (,Meghajnalodott arcán szép Piroska vére”) vagy egy vers keltette hangulat („A hangok a versben”).

Éder Zoltán az értékek szerelmese, elhivatottja volt: nem hagyta, hogy veszendőbe menjenek, a feledés martalékává váljanak. Éberen figyelt, megtalálta a számunkra érdektelennek tünő dolgokban a teljességet, a megismételhetetlen egyediséget. Mintha mindig a babitsi gondolat hajtotta volna: „A legkisebb ablakon át, mely a szabadba nyíl, végtelenig látni. A világ összefügg, és akármiről van szó, mindenről van szó” (Babits Mihály, Esszék, tanulmányok. Szépirodalmi Könyvkiadó, Budapest, 1978. 290). Egyetlen példa az „éderes” meseszövésre a Játékfilológia című kötetből: a tragikus sorsú költő, Békássy Ferenc lírai életrajzának felvázolására a család alkotóházzá alakított zsennyei kastélyában töltött pár nap indította. Előbb a falucska nevének történetéről, írásmódjának változásáról nyújt áttekintést, majd - a Magyar Irodalmi Lexikon és a Magyar Életrajzi Lexikon Gulyás Páltól eredeztethető rossz névírásának helyesbítése után - átvezet bennünket a két történelmi család, a Békássyak és a Bezerédyek legbensőbb világába. Megtudjuk, hogy a Bezerédy nagypapa Szegedy Antóniát, Kisfaludy Sándor hitvesének a húgát vette feleségül, s hogy leányuk, Amália a magyar óvodai nevelés fő kezdeményezője volt, fiuk, Bezerédy Elek (Békássy nagyapja) pedig Kis Emmát vette feleségül, aki nem volt más, mint Kazinczy költő barátjának, Kis Jánosnak az ükunokája. Szakavatott vezetésével megcsodálhatjuk a kastély könyvtárának kincseit (ez igazán Éder Zoltánnak tetsző foglalatoskodás), hagyja, hogy bepillantsunk a könyvtárból nyíló olvasófülkébe, ahol Bezerédy fogadta Deák Ferencet. De neki köszönhetően ugyanilyen otthonosan mozoghatunk Békássy tanulmányainak színhelyén, a cambridge-i King's College falai között vagy Virgina Woolf híres irodalmi szalonjában. Így köti össze nála egy név a kis Vas megyei falut a szellemi világ központjával, Cambridge-dzsel (i. m. 65-74).

Az Éder Zoltánról alkotott kép nem lenne teljes, ha említetlenül hagynám tanári, szakalapítói és szakterület-teremtői tevékenységét: a magyar mint idegen nyelv oktatása az ő kitartó munkájának köszönhetően lett az alkalmazott nyelvészet elfogadott részdiszciplínája, amit nappali szakká lett fénykorában is az általa kidolgozott elveket, tantárgyszerkezetet követve oktattak minden egyetemen. (Sajnálatos módon az a célja, hogy a magyar nyelvet minden tekintetben felkészült, a magyar nyelvészetben, kultúrában jártas, elhivatott, kellő módszertani ismeretekkel felvértezett, a szakmát tudományos szinten is müvelni képes tanárok oktassák, az oktatáspolitika szeszélyének betudhatóan mára veszélybe került.)

Éder Zoltán karizmatikus tanár volt. Már pályája kezdetén, a Könyvesben kivívta diákjai feltétlen szeretetét, csodálatát. A Játékfilológia címü könyv utolsó fejezetében az 
előtte tisztelgő volt diákjai - ma már meglett emberek, akik között van újságíró, orvos, kereskedelmi tanácsos, filmrendező, színész, zenész, tanár, könyvkiadó - mindnyájan az ő titkát próbálják megfejteni, szavakba önteni: miért is szerették annyira, mivel is írta be a lelkükbe magát egész életükre. Vajon mit tudhatott ez a magas, sportzakós, hamiskás mosolyú, szép, mastroiannis fiatalember, hogy ilyen megható férfiszeretettel idézték fel alakját? Mivel zabolázta meg, s tette az irodalom, a kultúra szerelmesévé a saját bevallása szerint is lógós ,újpesti csibész” diákját, vette rá őt és a többieket is, hogy önképzőkörben szerepeljenek, antológiát szerkesszenek, színjátszó szakkört hozzanak létre, hogy az alsópéli (KISZ) táborban a kukoricacímerezés, borsónyűvés után az ebédlőben Calderón-színdarabot adjanak elő? Pedig szigorú elvárásai voltak: memoriterfüzetet vezettetett, ahova bemásoltatta a megtanulandó verseket, nyárra (hosszú) kötelező olvasmánylistával látta el őket, és olvasónaplót is kellett írniuk. Számos magyarázattal szolgáltak a titkára: „törődött velünk, segített és bíztatott” (189); „El tudta velünk hitetni, hogy közösen valami nagyon fontos dolgon munkálkodunk” (182); „elérte, hogy mindig akarjunk valamit”; „Egyszerre nevelt bennünket igényessé, önállóvá és felelőssé” (i. h.). A végső válasz azonban valószínüleg csak ennyi: ő volt ,,az Éder tanár úr”.

Így igaz, nem volt könnyü az ő iskolájában tanulónak lenni! Jómagam, két kollégámmal, Hegedűs Ritával és a tragikusan korán elhunyt Kálmán Péterrel abban a szerencsében részesültünk, hogy a 80-as években, a magyar mint idegen nyelv szak létrehozásának úttörö éveiben mellette tanulhattunk, csiszolódhattunk, bontogathattuk szárnyainkat tanársegédként. Pályám során számtalanszor voltam hálás az akkoriban (nemegyszer) kelletlenül teljesített újra- és újrafogalmazásokért, javításokért, utánanézésekért. Már tudom, életre szóló, belülről kényszerítő örökséget kaptam tőle, amit - most, életem legnehezebb írásával küszködve is - hálásan köszönök.

Éder Zoltán tanár úr elnyerte a legfőbb jutalmat a sorstól, a Teremtőtől: noha fájdalmasan korán visszavonult, felesége-társa óvó, megtartó szeretetében szép, tartalmas éveket élhetett meg lemezei, kedves könyvei között. És megadatott neki a legnagyobb égi kegy: csendben, méltósággal mehetett el. Tisztelt Tanár Úr, nyugodjék békében!

SZILI KATALIN

Eperjesi Egyetem

\section{Búcsú Balogh Lajostól}

(1933-2020)*

Szomorú szívvel veszek búcsút Balogh Lajostól, az embertől, a tudományos kutatótól, a magyar nyelvjárások kitünő ismerőjétől, a magyar dialektológia elismert müvelöjétől. Távoztával jó barátot, pályatársat és közeli kollégát veszítettünk el. Búcsúzom tőle a Magyar Nyelvtudományi Társaságnak és az Eötvös Loránd Tudományegyetem Bölcsészettudományi Kara magyarnyelvészeinek a nevében.

*Elhangzott temetésén 2020. március 28-án Bükön, a Petőfi Sándor utcai temetőben.

DOI: 10.18349/MagyarNyelv.2020.2.241 